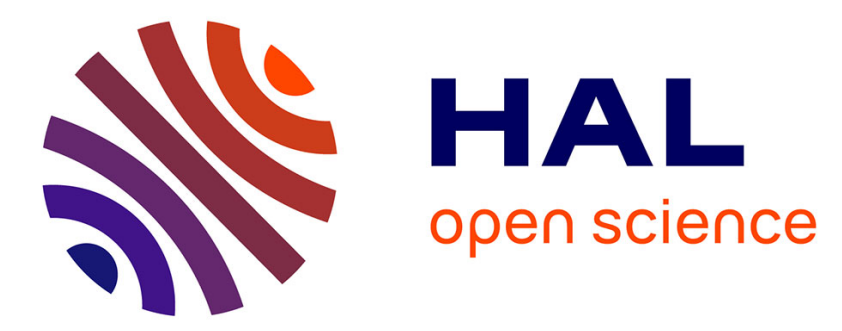

\title{
Pd-Catalyzed Selective Chlorination of Acrylamides at Room Temperature
}

\author{
Mu-Yi Chen, Xavier Pannecoucke, Philippe Jubault, Tatiana Besset
}

\section{To cite this version:}

Mu-Yi Chen, Xavier Pannecoucke, Philippe Jubault, Tatiana Besset. Pd-Catalyzed Selective Chlorination of Acrylamides at Room Temperature. Organic Letters, 2020, 22 (19), pp.7556-7561. 10.1021/acs.orglett.0c02750 . hal-03025282

\section{HAL Id: hal-03025282 \\ https://hal.science/hal-03025282}

Submitted on 8 Dec 2020

HAL is a multi-disciplinary open access archive for the deposit and dissemination of scientific research documents, whether they are published or not. The documents may come from teaching and research institutions in France or abroad, or from public or private research centers.
L'archive ouverte pluridisciplinaire HAL, est destinée au dépôt et à la diffusion de documents scientifiques de niveau recherche, publiés ou non, émanant des établissements d'enseignement et de recherche français ou étrangers, des laboratoires publics ou privés. 
Pd-Catalyzed Selective Chlorination of Acrylamides at Room Temperature.

Mu-Yi Chen, Xavier Pannecoucke, Philippe Jubault, and Tatiana Besset*

Normandie Univ, INSA Rouen, UNIROUEN, CNRS, COBRA (UMR 6014), 76000 Rouen, France.

ABSTRACT: In this manuscript, the transition metal catalyzed chlorination of alkenes was reported. In the presence of the commercially available and inexpensive $\mathrm{N}$-chlorosuccinimide and without additive, the Pd-catalyzed chlorination of acrylamides by $\mathrm{C}-\mathrm{H}$ bond activation was developed at room temperature under air. Under these mild reaction conditions, the versatility of the methodology was demonstrated as an array of acrylamides was functionalized to selectively provide the corresponding difficult-to-synthesize chlorinated olefins as a single $Z$ stereoisomer. Mechanistic studies were conducted to get insights into the reaction mechanism and post-functionalization reactions further demonstrated the synthetic utility of the approach towards the access to high value-added chlorinated compounds.

Chlorinated molecules are widely present in compounds of interest such as pharmaceuticals, agrochemicals and natural products. ${ }^{1}$ Especially, halogenation of aromatic derivatives is at the forefront of innovation since they have widespread applications in organic chemistry. Therefore, the development of novel methods to access them has attracted a strong interest from the scientific community. ${ }^{2}$ Among them, a special attention was paid to the transition metal catalyzed halogenation of aromatic derivatives by $\mathrm{C}-\mathrm{H}$ bond activation with $\mathrm{I}, \mathrm{Br}$ and $\mathrm{Cl}$ atoms. ${ }^{3}$ Indeed, transition metal catalyzed $\mathrm{C}-\mathrm{H}$ bond functionalizations have completely reshaped the field of organic chemistry. ${ }^{4}$ This straightforward tool for molecular synthesis further opened the chemical space, enabling applications to various fields. ${ }^{5}$ Especially, the transition metal catalyzed directed functionalization of the more challenging vinylic derivatives by $\mathrm{C}-\mathrm{H}$ bond activation was well studied over the years, offering a straightforward and selective access to the difficult-to-synthesize $Z$ isomer. 6 In sharp contrast, the halogenation of vinylic derivatives by $\mathrm{C}-\mathrm{H}$ bond activation ${ }^{6}$ still remains restricted to a handful of examples and requires to be further investigated as it offers a selective access to the challenging and ubiquitous $Z$ olefinic moiety. The quest to efficient and selective tools towards the difficult-to-synthesize Z-olefins is of high importance, since this scaffold might be found in several bioactive compounds such as Selinexor ${ }^{\circledR}$.

In the realm of transition metal catalyzed halogenation of olefins by $\mathrm{C}-\mathrm{H}$ activation, bromination and iodination reactions were mainly studied using various transition metal catalysts and led to major contributions. In 2013, Glorius reported the Rh(III)catalyzed bromination and iodination of acrylamides ${ }^{7}$ and one year later they depicted the iodination of acrylamides $^{8}$ via a Cp*Co(III) catalysis. In 2019, Carreira described the Pd-catalyzed iodination of unactivated olefins using picolamide as a directing group (Scheme 1). ${ }^{9}$ However, the direct and regioselective synthesis of $Z$-chlorinated acrylic acid derivatives is still elusive despite the clear interest of the corresponding vinyl chloride compounds. ${ }^{1}$ Therefore, the elaboration of a new synthetic approach towards these chlorinated molecules represents a significant challenge in modern organic chemistry and is still an unmet goal. Up to date, the existing methods to synthesize $Z$ - $\beta$-chloroacrylic acid derivatives generally relied on a Vilsmeier-Haack reaction, $^{10}$ a Wittig reaction, ${ }^{11}$ a chloropalladation/Heck reaction sequence, ${ }^{12}$ chlorination of propagyl alcohols, ${ }^{13}$ as well as hydrochlorination, ${ }^{14}$ chloroacylation ${ }^{15}$ and chlorocarbonylation ${ }^{16}$ reactions of alkynes, among others. A lack of $E / Z$ selectivity or the need to have the proper alkynes are the main synthetic limitations of these methods that are needed to be overcome. In addition, to meet the continuous demand for more sustainable transformations, the development of $\mathrm{C}-\mathrm{H}$ activation reactions under mild conditions (no additives, room temperature) is still highly desirable. Keeping these considerations in mind and pursuing our current interest towards the functionalization of vinylic derivatives by $\mathrm{C}-\mathrm{H}$ bond activation, ${ }^{17}$ we report herein the unprecedented $\mathrm{Pd}(\mathrm{II})$-catalyzed 
chlorination of various $\alpha$ - and $\alpha, \beta$-substituted acrylamide derivatives at room temperature.

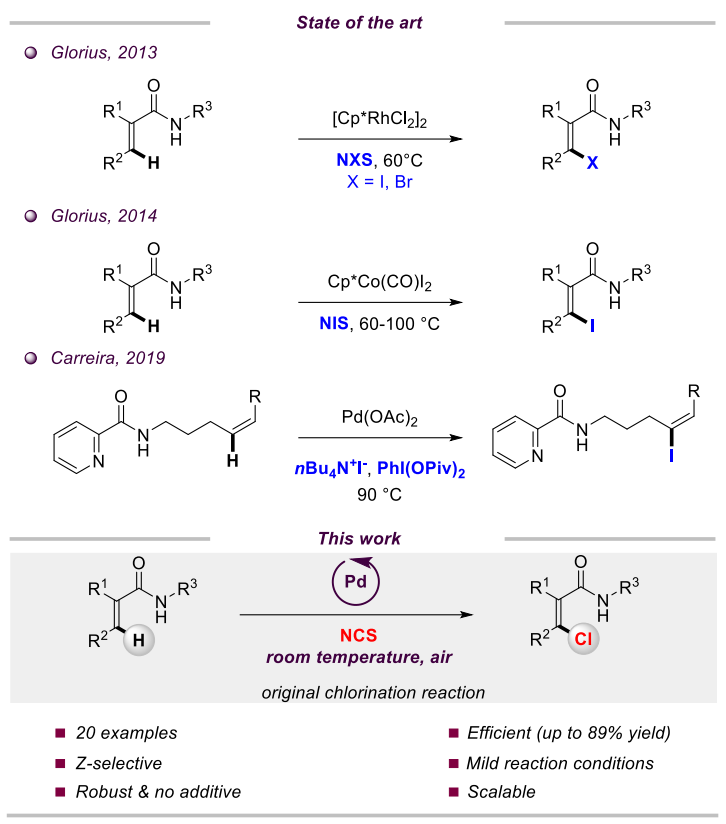

Scheme 1. State of the art and present work.

At the outset of the study, the Pd-catalyzed chlorination of the $\alpha$-phenylacrylamide $1 \mathrm{a}$ was studied (Table 1). In the presence of a stoichiometric amount of NCS and using $\mathrm{PdCl}_{2}$ as a catalyst, 1a was smoothly converted into the corresponding chlorinated product $\mathbf{2 a}$ in $85 \%$ yield under an air atmosphere in $8 \mathrm{~h}$ (Table 1 , entry 1 ). The reaction turned out to be completely diastereoselective as a single Z-isomer was obtained as ascertained by $2 \mathrm{D}$ NMR experiments. ${ }^{18}$ The replacement of $\mathrm{PdCl}_{2}$ by other copper-based catalysts (Table 1 , entries 2 and 3 ) led to no expected product $\mathbf{2 a}$, and only the product resulting from the chlorination at the $\mathrm{C} 5$ position of the 8-aminoquinoline part was observed. The catalyst loading was also important to selectively get the functionalization of the olefin. Indeed, when $5 \mathrm{~mol} \%$ of the catalyst was used, the reaction furnished $2 \mathbf{a}$ in only $25 \%$ yield, along with the chlorinated product on the aminoquinoline part (Table 1 , entry 4). A control experiment was conducted and in the absence of catalyst, $2 \mathrm{a}$ was not obtained and the same sidereaction was prominent (Table 1 , entry 5 ). Increasing the reaction time (Table 1 , entry 6 ) or running the reaction under inert atmosphere (Table 1 , entry 7 ) did not have any significant impact on the outcome of the reaction. Finally, using non-distilled DMF or a mixture of DMF/ $\mathrm{H}_{2} \mathrm{O}$ (9:1), the reaction afforded $2 \mathrm{a}$ albeit in somehow lower yields (Table 1, entries 8 and 9), showcasing hence the robustness of the transformation. Note that attempts to extend the reaction to the bromination of 1a was unsuccessful. ${ }^{19}$

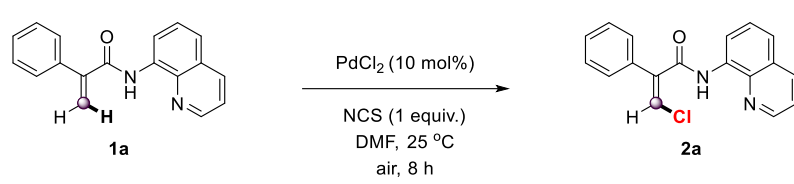

\begin{tabular}{lll}
\hline entry & $\begin{array}{l}\text { variation from standard } \\
\text { conditions }\end{array}$ & $\begin{array}{l}\text { yields } \\
(\%)^{a}\end{array}$ \\
\hline 1 & None & 85 \\
2 & Cul instead of $\mathrm{PdCl}_{2}$ & 0 \\
3 & $\mathrm{CuCl}_{2}$ instead of $\mathrm{PdCl}_{2}$ & 0 \\
4 & $\begin{array}{l}5 \text { mol\% of } \mathrm{PdCl}_{2} \text { instead of } 10 \\
\text { mol\% }\end{array}$ & $25^{b}$
\end{tabular}

$5 \quad$ No catalyst $\quad 0$

$6 \quad 16 \mathrm{~h}$ instead of $8 \mathrm{~h} \quad 82$

$7 \quad$ Ar atmosphere instead of air 83

$8 \quad$ No distilled DMF instead of 75 distilled one

$9 \quad \mathrm{DMF} / \mathrm{H}_{2} \mathrm{O} \quad(9: 1)$ instead of 48 DMF

Table 1. Reaction of 1a with NCS: optimization studies. ${ }^{a}$ Isolated yields. All reactions were performed on a 0.2 mmol scale. ${ }^{b}$ The product was obtained along with the product resulting from the chlorination at the $\mathrm{C} 5$ position of the 8 -aminoquinoline part in $31 \%$ yield.

With the best reaction conditions in hand, an access to tri-substituted acrylamides was achieved via the Pd-catalyzed chlorination of an array of $\alpha$-arylsubstituted acrylamides (Scheme 2, 2a-2q). When 1a was used as the substrate, the reaction was efficiently 20 -fold time scaled up, offering an access to about $1 \mathrm{~g}$ of $2 \mathrm{a}(0.99 \mathrm{~g}, 80 \%)$ without erosion of the yield $(85 \%$ on $0.2 \mathrm{mmol}$ scale). The reaction turned out to be highly regio- and diastereo-selective to the expected 
product and only the mono-chlorination of the olefin part was observed. Several acrylamides bearing an arene at the $\alpha$-position substituted by an electrondonating (1)-e) group or halogens (1f-i) at the para position were chlorinated. The reaction was also tolerant to the trifluoromethyl group (2k). Meta and ortho substituted ?-aryl acrylamides (2j-20) were chlorinated and the substitution pattern on the arenes did not have any impact on the efficiency of the transformation (similar yields for compounds $\mathbf{2} \mathbf{b}, \mathbf{2} \mathbf{j}$, $\mathbf{2 m}$ ). Note that the structure of $\mathbf{2 n}$ was further confirmed by X-ray analysis (CCDC 2016282). ${ }^{20}$ Acrylamides with disubstituted arenes (1p and $\mathbf{1 q}$ ) were also suitable substrates in this transformation. The methodology was successfully extended to the chlorination of the methacrylamide $\mathbf{1 r}$ leading to the corresponding product $\mathbf{2}$ in $53 \%$ yield.

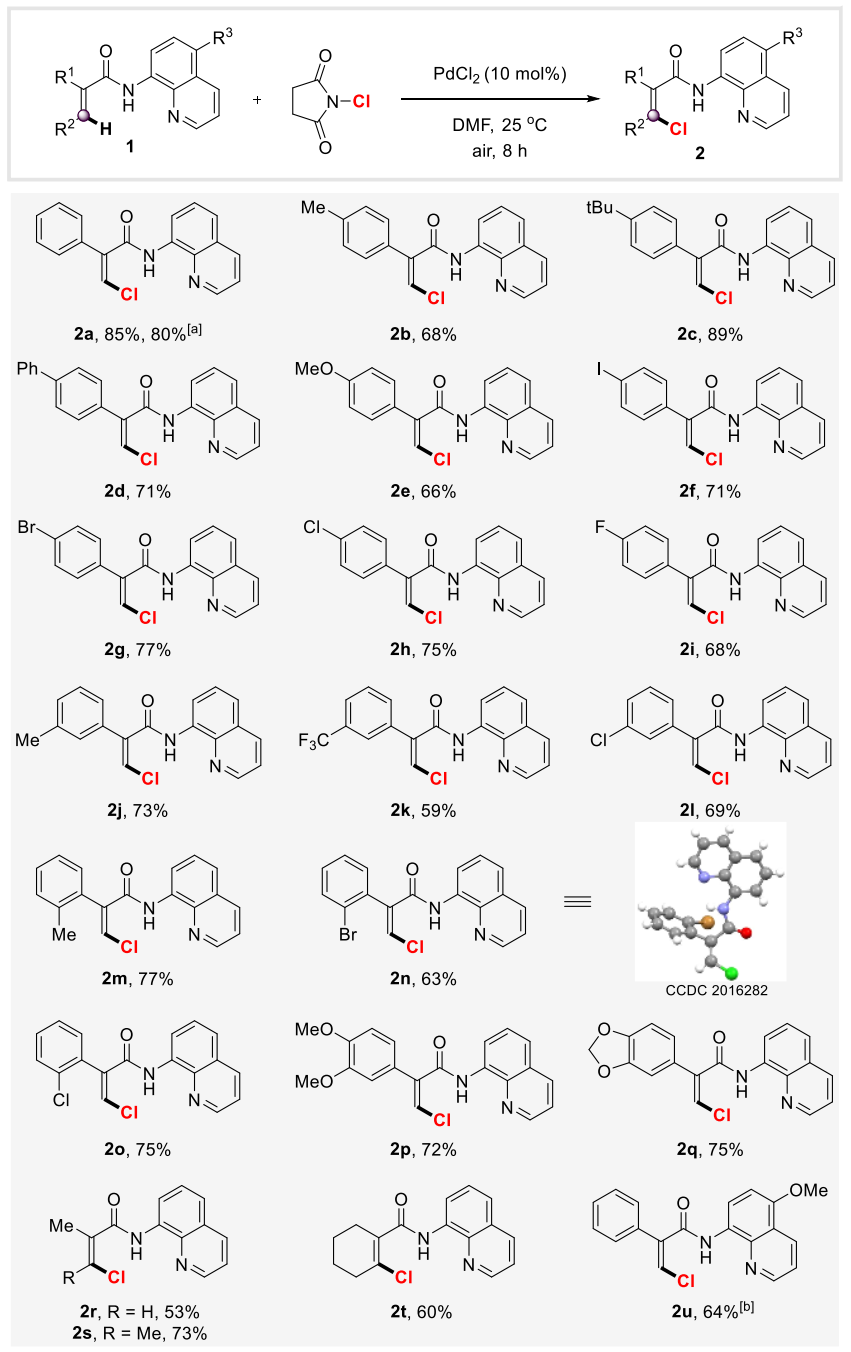

Reaction conditions: acrylamide $1(0.2 \mathrm{mmol})$, NCS (1 equiv.), $\mathrm{PdCl}_{2}(10 \mathrm{~mol} \%), \mathrm{DMF}(2 \mathrm{~mL}), 25^{\circ} \mathrm{C}, 8 \mathrm{~h}$, air. Isolated yields were given. ${ }^{a}$ Reaction performed on $4 \mathrm{mmol}$ scale (1.1 g of 1a), 20 h. ${ }^{b} 20 \mathrm{~h}$.

Pleasingly, the approach was successfully applied to the functionalization of the $\alpha, \beta$-substituted acrylamides, the stereoselective access to tetrasubstituted acyclic olefin being still a synthetic challenge. ?,?-Substituted acrylamides such as the dimethyl acrylamide (1s) and the cyclohex-1enecarboxamide (1t) were smoothly converted into the fully decorated olefins $\mathbf{2 s}$ and $\mathbf{2 t}$. Even the amide derived from the 5-methoxy-8-aminoquinoline $1 \mathrm{u}$ was smoothly functionalized in a longer time.

To further illustrate the modularity of the chlorinated amides, they were easily converted into other classes of compounds. The directing group was cleaved under various reaction conditions (Scheme 3 ). When $\mathbf{2 a}$ and $\mathbf{2} \mathbf{u}$ were engaged under acidic or oxidative conditions, the corresponding ester $\mathbf{3}$ and the primary amide $\mathbf{4}$ were obtained in $55 \%$ and $77 \%$ yields, respectively.

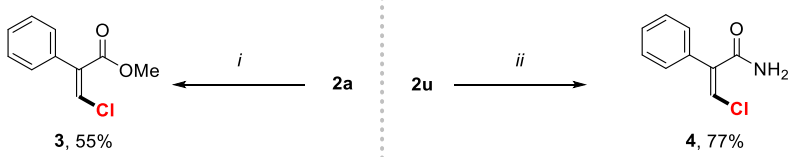

Scheme 3. Deprotection of the directing group.

i: $\mathrm{TsOH}$ (3 equiv.), $\mathrm{MeOH}(0.2 \mathrm{M}), 100^{\circ} \mathrm{C}, 7$ days, Ar. ii: CAN (3 equiv.), $\mathrm{MeCN} / \mathrm{H}_{2} \mathrm{O}(5: 1,0.3 \mathrm{M}), 25^{\circ} \mathrm{C}, 16 \mathrm{~h}$, Ar.

Taking benefit from the versatility brought by the introduction of a chlorine atom on the olefinic derivative as a "synthetic transformable handle" for post-functionalization, we investigated further structural modifications by the transformation of the carbon-chlorine bond into other carbon-functional groups (Scheme 4). Reaction of $\mathbf{2 a}$ with morpholine led to the corresponding product $\mathbf{5}$ as the single $E$ isomer, ascertained by NMR. ${ }^{18}$ Subsequent thiolation of $2 a$ provided an inseparable $Z / E$ mixture of the thiolated compound $(6 \mathbf{6} / \mathbf{6 b})$ in $75 \%$ yield, the $Z$ isomer being the major one. ${ }^{21}$ Moreover, taking benefit from the presence of an iodine atom on the aromatic ring of $\mathbf{2} \mathbf{f}$, a Suzuki reaction was performed leading to the corresponding compound $\mathbf{7}$, the

Scheme 2. Scope of the chlorination reaction. 
chlorinated olefin part remaining intact at the end of the reaction.

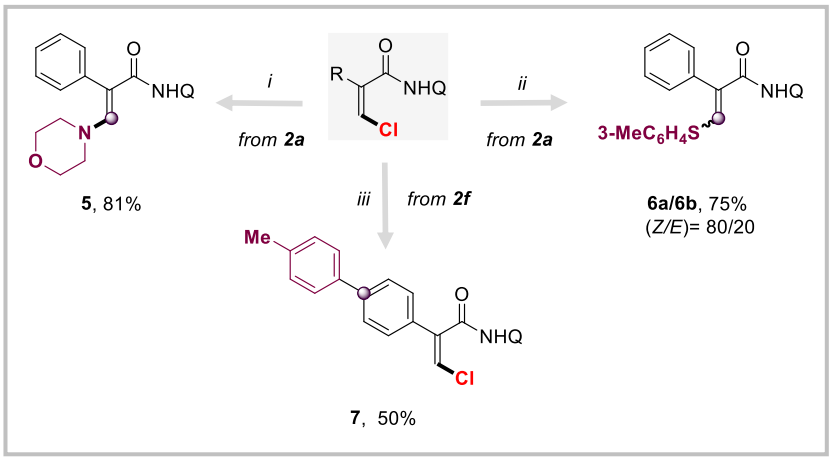

Scheme 4. Synthetic Applications.

Reactions were carried out on $0.1 \mathrm{mmol}$ scale. Isolated yields were given. $i$. Morpholine (1.5 equiv.), DMF ( $0.2 \mathrm{M})$, $90{ }^{\circ} \mathrm{C}, 16 \mathrm{~h}$, Ar. ii. 3-Methylbenzenethiol (1.5 equiv.), $\mathrm{Et}_{3} \mathrm{~N}$ (1.5 equiv.), DMF (0.2 M), $50{ }^{\circ} \mathrm{C}, 24$ h, Ar. iii. $\mathrm{Pd}\left(\mathrm{PPh}_{3}\right)_{4}(5$ mol\%), $p$-tolylboronic acid (2 equiv.), $\mathrm{K}_{2} \mathrm{CO}_{3}$ (1.5 equiv.), toluene (0.2 M), $100^{\circ} \mathrm{C}, 16 \mathrm{~h}, \mathrm{Ar} . \mathrm{Q}=8$-quinolyl.

To gain more insight into the mechanism of the reaction, several experiments were conducted..$^{18}$ First, when scrambling experiments were performed, a H/D exchange was observed, suggesting that the $\mathrm{C}-\mathrm{H}$ bond activation step is reversible. Then, $\mathbf{1} \mathbf{i}$ and the isotopically labeled olefin [D]-1i were engaged in parallel reactions and a kinetic isotopic effect (KIE) of 2.1 was measured. These results indicated that the rate-determining step is most likely the palladacycle formation. Experiments conducted with $1 \mathrm{a}$ in the presence of TEMPO, BHT and 1,4-dinitrobenezene as radical scavengers showed no significant effect on the outcome of the reaction, the reaction was just slowed down (remaining unreacted $\mathbf{1 a}$ at the end of the reaction), explaining the slightly lower yields. ${ }^{18}$ Therefore, a radical process might be ruled out. Based on these considerations, the following plausible mechanism was suggested: at first, coordination of the $\mathrm{Pd}(\mathrm{II})$ catalyst with the bidentate directing group of $1 \mathbf{a}$ followed that the reversible formation of the palladacycle II. This latter underwent an oxidative addition followed by a reductive elimination to furnish the expected product $\mathbf{2} \mathbf{a}$ and to regenerate the catalyst (Scheme 5). Note that a redox neutral Pd(II)based mechanism might not be excluded. ${ }^{22}$

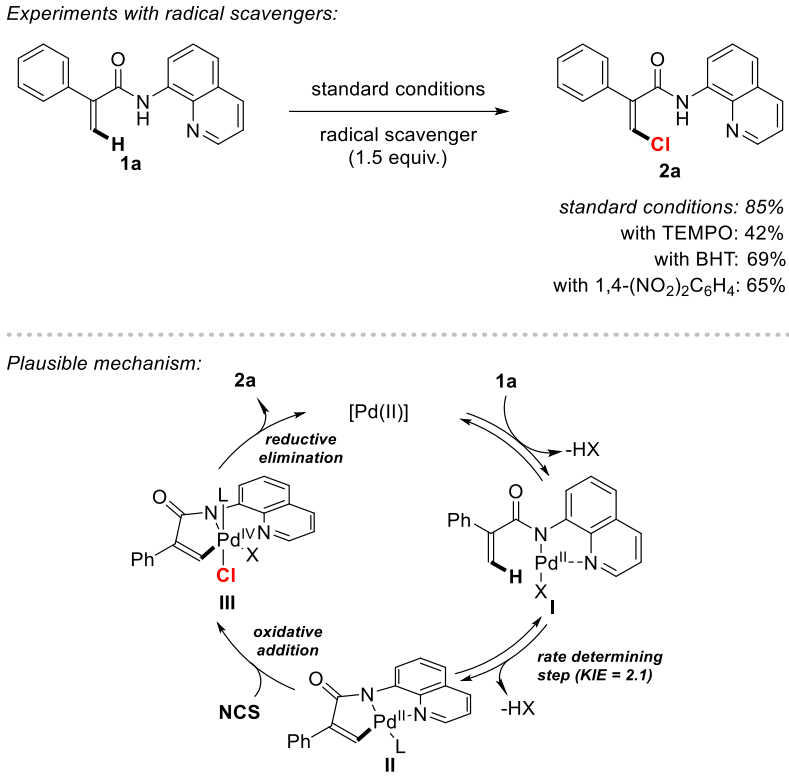

Scheme 5. Suggested mechanism.

In summary, we developed a new methodology allowing the direct chlorination of acrylamide derivatives under $\mathrm{Pd}$ catalysis by $\mathrm{C}-\mathrm{H}$ bond activation. This approach offered an access to tri- and tetrasubstituted olefins in a complete stereoselective manner towards the $Z$-isomer (20 examples, up to $89 \%$ yield). This original transformation occurred at room temperature and was suitable with a broad variety of acrylamides. Indeed, $\alpha$-substituted and $\alpha, \beta$ disubstituted acrylamide derivatives were efficiently functionalized. The salient features of this chlorination transformation are the lack of additives (oxidant, ligand, acid or base...), the air and moisture tolerance, a total control of the regio- and diasteroselectivity, the very mild reaction conditions (room temperature) and an easy scale-up. Moreover, access to value-added scaffolds, which hinged on the use of the chlorine atom as a linchpin, demonstrated further the key importance of chlorinated compounds and the need to develop methodologies to reach them. By tackling an unmet synthetic goal, this new approach considerably extended the portfolio of chlorinated molecules and paved the way towards original synthetic routes to unsaturated chlorinated compounds.

\section{ACKNOWLEDGMENT}

This work was partially supported by Normandie Université (NU), the Région Normandie, the Centre National de la Recherche Scientifique (CNRS), 
Université de Rouen Normandie (URN), INSA Rouen Normandie, Labex SynOrg (ANR-11-LABX-0029), the French National Research Agency (ANR-17-CE070038-01) and Innovation Chimie Carnot (I2C). T.B. thanks the European Research Council (ERC) under the European Union's Horizon 2020 research and innovation program (grant agreement no. 758710). M.-Y.C. thanks the French National Research Agency for a doctoral fellowship (ANR-17-CE07-0038-01). We are thankful to Prof. Hassan Oulyadi for his help for NMR analysis.

\section{REFERENCES}

(1) (a) Engvild, K. C. Chlorine Containing Natural Compounds in Higher Plants. Phytochemistry 1986, 25, 781-791. (b) Gribble, G. W. Naturally Occurring Organohalogen Compounds. Acc. Chem. Res. 1998, 31, 141-152. (c) Hernandes, M. Z.; Cavalcanti, S. M. T.; Moreira, D. R. M.; de Azevedo Junior, W. F.; Leite, A. C. L. Halogen Atoms in the Modern Medicinal Chemistry: Hints for the Drug Design. Curr Drug Targets 2010, 11, 303-314. (d) Jeschke, P. The Unique Role of Halogen Substituents in the Design of Modern Agrochemicals. Pest. Manag. Sci. 2009, 66, 10-27.

(2) For selected reviews, see: (a) Petrone, D. A.; Ye, J.; Lautens, M. Modern Transition-Metal-Catalyzed Carbon-Halogen Bond Formation. Chem. Rev. 2016, 116, 8003-8104. (b) Shi, X.; Shi, D. Recent Advances in Transition-Metal-Catalyzed Halides Formation. Current Org. Chem. 2018, 22, 2229-2255. (c) Joseph, P. J. A.; Priyadarshini, S. Copper-Mediated C-X Functionalization of Aryl Halides. Org. Process Res. Dev. 2017, 21, 1889-1924. For selected examples, see: (d) Yu, P.; Bismuto, A.; Morandi, B. IridiumCatalyzed Hydrochlorination and Hydrobromination of Alkynes by Shuttle Catalysis. Angew. Chem. Int. Ed. 2020, 59, 2904-2910. (e) Shi, J.-L.; Zhang, J.-C.; Wang, B.-Q.; Hu, P.; Zhao, K.-Q.; Shi, Z.-J. Fe-Promoted Chlorobenzylation of Terminal Alkynes Through Benzylic C(Sp(3))-H Bond Functionalization. Org. Lett. 2016, 18, 1238-1241. (f) Ebule, R.; Liang, S.; Hammond, G. B.; Xu, B. Chloride-Tolerant Gold(I)Catalyzed Regioselective Hydrochlorination of Alkynes. ACS Catal. 2017, 7, 6798-6801. (g) Shi, C.; Miao, Q.; Ma, L.; Lu, T.; Yang, D.; Chen, J.; Li, Z. RoomTemperature $\mathrm{C}-\mathrm{H}$ Bromination and lodination with Sodium Bromide and Sodium lodide Using $\mathrm{N}$ -
Fluorobenzenesulfonimide as an Oxidant. ChemistrySelect 2019, 4, 6043-6047.

(3) For selected reviews, see: (a) Lied, F.; Patra, T.; Glorius, F. Group 9 Transition Metal-Catalyzed C-H Halogenations. Isr. J. Chem. 2017, 57, 945-952. (b) Das, R.; Kapur, M. Transition-Metal-Catalyzed SiteSelective $\mathrm{C}-\mathrm{H}$ Halogenation Reactions. Asian J. Org. Chem. 2018, 7, 1524-1541. (c) Hao, W.; Liu, Y. C-H Bond Halogenation Catalyzed or Mediated by Copper: an Overview. Beilstein J. Org. Chem. 2015, 11, 21322144. (d) Li, X.; Ouyang, W.; Nie, J.; Ji, S.; Chen, Q.; Huo, Y. Recent Development on Cp*Ir(III)-Catalyzed $\mathrm{C}-\mathrm{H}$ Bond Functionalization. ChemCatChem 2020, 12, 2358-2384.

(4) For selected reviews, see: (a) Lyons, T. W.; Sanford, M. S. Palladium-Catalyzed Ligand-Directed $\mathrm{C}-\mathrm{H}$ Functionalization Reactions. Chem. Rev. 2010, 110, 1147-1169. (b) Jazzar, R.; Hitce, J.; Renaudat, A.; Sofack-Kreutzer, J.; Baudoin, O. Functionalization of Organic Molecules by Transition-Metal-Catalyzed C(Sp3)-H Activation. Chem. Eur. J. 2010, 16, 26542672. (c) Engle, K. M.; Mei, T.-S.; Wasa, M.; Yu, J.-Q. Weak Coordination as a Powerful Means for Developing Broadly Useful C-H Functionalization Reactions. Acc. Chem. Res. 2012, 45, 788-802. (d) Chen, Z.; Wang, B.; Zhang, J.; Yu, W.; Liu, Z.; Zhang, Y. Transition Metal-Catalyzed $\mathrm{C}-\mathrm{H} \quad$ Bond Functionalizations by the Use of Diverse Directing Groups. Org. Chem. Front. 2015, 2, 1107-1295. (e) Pototschnig, G.; Maulide, N.; Schnürch, M. Direct Functionalization of $\mathrm{C}-\mathrm{H}$ Bonds by Iron, Nickel, and Cobalt Catalysis. Chem. Eur. J. 2017, 23, 9206-9232. (f) Sambiagio, C.; Schönbauer, D.; Blieck, R.; Dao-Huy, T.; Pototschnig, G.; Schaaf, P.; Wiesinger, T.; Zia, M. F.; Wencel-Delord, J.; Besset, T.; Maes, B. U. W.; Schnürch, M. A Comprehensive Overview of Directing Groups Applied in Metal-Catalysed C-H Functionalisation Chemistry. Chem. Soc. Rev. 2018, 47, 6603-6743. (g) Ma, C.; Fang, P.; Mei, T.-S. Recent Advances in $\mathrm{C}-\mathrm{H}$ Functionalization Using Electrochemical Transition Metal Catalysis. ACS Catal. 2018, 8, 7179-7189. (h) Gandeepan, P.; Müller, T.; Zell, D.; Cera, G.; Warratz, S.; Ackermann, L. 3d Transition Metals for C-H Activation. Chem. Rev. 2019, 119, 2192-2452. (i) For an issue on $\mathrm{C}-\mathrm{H}$ bond activation, see: Chem. Rev. 2017, 117, 8481-9520. 
(5) For selected examples, see: (a) Wang, W.; Lorion, M. M.; Shah, J.; Kapdi, A. R.; Ackermann, L. Late-Stage Peptide Diversification by Position-Selective $\mathrm{C}-\mathrm{H}$ Activation. Angew. Chem. Int. Ed. 2018, 57, 1470014717. (b) Noisier, A. F. M.; Brimble, M. A. C-H Functionalization in the Synthesis of Amino Acids and Peptides. Chem. Rev. 2014, 114, 8775-8806. (c) Pouliot, J.-R.; Grenier, F.; Blaskovits, J. T.; Beaupré, S.; Leclerc, M. Direct (Hetero)Arylation Polymerization: Simplicity for Conjugated Polymer Synthesis. Chem. Rev. 2016, 116, 14225-14274. (d) Schipper, D. J.; Fagnou, K. Direct Arylation as a Synthetic Tool for the Synthesis of Thiophene-Based Organic Electronic Materials. Chem. Mater. 2011, 23, 1594-1600. (e) Seki, M. A New Catalytic System for Ru-Catalyzed C-H Arylation Reactions and Its Application in the Practical Syntheses of Pharmaceutical Agents. Org. Process Res. Dev. 2016, 20, 867-877. (f) Ackermann, L. Robust Ruthenium(II)-Catalyzed C-H Arylations: Carboxylate Assistance for the Efficient Synthesis of AngiotensinII-Receptor Blockers. Org. Process Res. Dev. 2015, 19, 260-269. (g) Cernak, T.; Dykstra, K. D.; Tyagarajan, S.; Vachal, P.; Krska, S. W. The Medicinal Chemist's Toolbox for Late Stage Functionalization of Drug-Like Molecules. Chem. Soc. Rev. 2016, 45, 546-576. (h) Karimov, R. R.; Hartwig, J. F. Transition-MetalCatalyzed Selective Functionalization of $\mathrm{C}(\mathrm{Sp} 3)-\mathrm{H}$ Bonds in Natural Products. Angew. Chem. Int. Ed. 2018, 57, 4234-4241. (i) Abrams, D. J.; Provencher, P. A.; Sorensen, E. J. Recent Applications of $\mathrm{C}-\mathrm{H}$ Functionalization in Complex Natural Product Synthesis. Chem. Soc. Rev. 2018, 47, 8925-8967. (j) Baudoin, O. Multiple Catalytic C-H Bond Functionalization for Natural Product Synthesis. Angew. Chem. Int. Ed. 2020, 10.1002/anie.202001224 and references therein.

(6) For selective reviews on transition metal catalyzed $\mathrm{C}-\mathrm{H}$ activation of vinylic derivatives, see: (a) Besset, T.; Poisson, T.; Pannecoucke, X. Recent Progress in Direct Introduction of Fluorinated Groups on Alkenes and Alkynes by Means of $\mathrm{C}-\mathrm{H}$ Bond Functionalization. Chem. Eur. J. 2014, 20, 16830-16845. (b) Wang, K.; Hu, F.; Zhang, Y.; Wang, J. Directing Group-Assisted Transition-Metal-Catalyzed Vinylic $\mathrm{C}-\mathrm{H}$ Bond Functionalization. Sci. China Chem. 2015, 58, 12521265 and references therein. (c) Maraswami, M.; Loh, T.-P. Transition-Metal-Catalyzed Alkenyl $\mathrm{Sp}^{2} \mathrm{C}-\mathrm{H}$
Activation: a Short Account. Synthesis 2019, 51, 10491062. (d) Liu, C.; Yuan, J.; Gao, M.; Tang, S.; Li, W.; Shi, R.; Lei, A. Oxidative Coupling between Two Hydrocarbons: An Update of Recent $\mathrm{C}-\mathrm{H}$ Functionalizations. Chem. Rev. 2015, 115, 1213812204 and references therein. For selected examples, see: (e) Besset, T.; Kuhl, N.; Patureau, F. W.; Glorius, F.

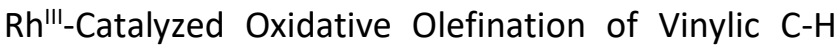
Bonds: Efficient and Selective Access to Diunsaturated $\alpha$-Amino Acid Derivatives and Other Linear 1,3-Butadienes. Chem. Eur. J. 2011, 17, 71677171. (f) Zhang, J.; Loh, T.-P. Ruthenium- and rhodiumcatalyzed cross-coupling reaction of acrylamides with alkenes: efficient access to $(Z, E)$-dienamides. Chem. Commun. 2012, 48, 11232-11234. (g) Li, F.; Yu, C.; Zhang, J.; Zhong, G. Olefination of Electron-Deficient Alkenes with Allyl Acetate: Stereo- and Regioselective Access to (2Z,4E)-Dienamides. Org. Lett. 2016, 18, 4582-4585. (h) Wen, Z.-K.; Xu, Y.-H.; Loh, T.-P. Palladium(ii)-catalyzed cross-coupling of simple alkenes with acrylates: a direct approach to 1,3-dienes through $\mathrm{C}-\mathrm{H}$ activation. Chem. Sci. 2013, 4, 45204524. (i) Neely, J. M.; Rovis, T. Rh(III)-Catalyzed Regioselective Synthesis of Pyridines from Alkenes and $\alpha, \beta$-Unsaturated Oxime Esters. J. Am. Chem. Soc. 2013, 135, 66-69. (j) Hu, X.-H.; Zhang, J.; Yang, X.-F.; $\mathrm{Xu}, \mathrm{Y} .-\mathrm{H} . ;$ Loh, T.-P. Stereo- and Chemoselective CrossCoupling between Two Electron-Deficient Acrylates: An Efficient Route to $(Z, E)$-Muconate Derivatives. J. Am. Chem. Soc. 2015, 137, 3169-3172. (k) Giri, R.; Yu, J.-Q. Synthesis of 1,2- and 1,3-Dicarboxylic Acids via $\mathrm{Pd}$ (II)-Catalyzed Carboxylation of Aryl and Vinyl C-H Bonds. J. Am. Chem. Soc. 2008, 130, 14082-14083.

(7) Kuhl, N.; Schröder, N.; Glorius, F. Rh(III)-Catalyzed Halogenation of Vinylic C-H Bonds: Rapid and General Access to Z-Halo Acrylamides. Org. Lett. 2013, 15, 3860-3863.

(8) Yu, D.-G.; Gensch, T.; de Azambuja, F.; VásquezCéspedes, S.; Glorius, F. Co(III)-Catalyzed C-H Activation/Formal $\mathrm{S}_{\mathrm{N}}$-Type Reactions: Selective and Efficient Cyanation, Halogenation, and Allylation. J. Am. Chem. Soc. 2014, 136, 17722-17725.

(9) Schreib, B. S.; Carreira, E. M. Palladium-Catalyzed Regioselective $\mathrm{C}-\mathrm{H}$ lodination of Unactivated Alkenes. J. Am. Chem. Soc. 2019, 141, 8758-8763. 
(10) Krishnaraj, K. U.; Devaky, K. S. Synthesis of 2Hydroxy-5,6-Diarylnicotinonitriles and 2-Chloro- 5,6Diarylnicotinonitriles From. Tetrahedron 2014, 70, 6450-6456.

(11) Moody, C. J.; Pass, M.; Rees, C. W.; Tojo, G. Synthesis of the Left-Hand Unit of the Antitumour Agent CC-1065. J. Chem. Soc., Chem. Commun. 1986, 1062-1063.

(12) Huang, J.-M.; Dong, Y.; Wang, X.-X.; Luo, H.-C. Highly Regio- and Stereoselective Intermolecular Tandem Reaction to Synthesize Chloro-Substituted 1,3-Butadienes. Chem. Commun. 2010, 46, 10351037.

(13) Trost, B. M.; Tracy, J. S. Vanadium-Catalyzed Synthesis of Geometrically Defined Acyclic Tri- and Tetrasubstituted Olefins From Propargyl Alcohols. ACS Catal. 2019, 9, 1584-1594.

(14) (a) Ma, S.; Lu, X.; Li, Z. A Novel Regio- and Stereospecific Hydrohalogenation Reaction of 2Propynoic Acid and Its Derivatives. J. Org. Chem. 1992, 57, 709-713. (b) Grannas, M. J.; Hoskins, B. F.; Robson, R. A New Tetranucleating Tetra-Amino-Tetra-Phenolic Macrocyclic Ligand and the Crystal Structure of a $\mathrm{Zn}_{4}$ Derivative. J. Chem. Soc., Chem. Commun. 1990, 1644-1646. (c) Taniguchi, M.; Kobayashi, S.; Nakagawa, M.; Hino, T.; Kishi, Y. ? ?-Halovinyl Ketones : Synthesis from Acetylenic Ketones. Tetrahedron Lett. 1986, 27, 4763-4766.

(15) (a) Cano, R.; Yus, M.; Ramón, D. J. Catalyzed Addition of Acid Chlorides to Alkynes by Unmodified Nano-powder Magnetite: Synthesis of Chlorovinyl Ketones, Furans, and Related Cyclopentenone Derivatives. Tetrahedron 2013, 69, 7056-7065. (b) Zhou, H.; Zeng, C.; Ren, L.; Liao, W.; Huang, X. $\mathrm{GaCl}_{3}$ Catalyzed Chloroacylation of Alkynes: a Simple, Convenient and Efficient Method to ?-Chlorovinyl Ketones. Synlett 2006, 3504-3506. (c) Koo, H.; Kim, H. Y.; Oh, K. (E)-Selective Friedel-Crafts Acylation of Alkynes to ?-Chlorovinyl Ketones: Defying Isomerizations in Batch Reactions by Flow Chemistry Approaches. Org. Chem. Front. 2019, 6, 1868-1872.

(16) (a) Cantagrel, G.; de Carné-Carnavalet, B.; Meyer, C.; Cossy, J. Iron Trichloride-Promoted Cyclization of O-Alkynylaryl Isocyanates: Synthesis of 3-
(Chloromethylene)Oxindoles. Org. Lett. 2009, 11, 4262-4265. (b) Tang, S.; Yu, Q.-F.; Peng, P.; Li, J.-H.; Zhong, P.; Tang, R.-Y. Palladium-Catalyzed Carbonylative Annulation Reaction of 2-(1Alkynyl)Benzenamines: Selective Synthesis of 3(Halomethylene)Indolin-2-Ones. Org. Lett. 2007, 9, 3413-3416. (c) Baek, J. Y.; Lee, S.; Sim, S.; Chung, Y. Chloroesterification of Enynes Catalyzed by $\mathrm{NHC}$ Rhodium Compounds. Synlett 2008, 551-554. (d) Hua, R.; Onozawa, S.-Y.; Tanaka, M. Rhodium-Catalyzed Nondecarbonylative Addition Reaction of $\mathrm{ClCOCOOC}_{2} \mathrm{H}_{5}$ to Alkynes. Chem. Eur. J. 2005, 11, 3621-3630. (e) Le, C. M.; Sperger, T.; Fu, R.; Hou, X.; Lim, Y. H.; Schoenebeck, F.; Lautens, M. Stereoselective Synthesis of Methylene Oxindoles via Palladium(II)-Catalyzed Intramolecular Cross-Coupling of Carbamoyl Chlorides. J. Am. Chem. Soc. 2016, 138, 14441-14448.

(17) (a) Chen, M.-Y.; Pannecoucke, X.; Jubault, P.; Besset, T. Access to Isothiazolones From Simple Acrylamides by Pd-Catalyzed C-H Bond Activation. J. Org. Chem. 2019, 84, 13194-13202. (b) Zhao, Q.; Chen, M.-Y.; Poisson, T.; Pannecoucke, X.; Bouillon, J.P.; Besset, T. Pd-Catalyzed Trifluoromethylthiolation of Unsaturated Compounds: a General Approach. Eur. J. Org. Chem. 2018, 6167-6175. (c) Zhao, Q.; Wang, J.; Besset, T.; Pannecoucke, X.; Bouillon, J.-P.; Poisson, T. Palladium-catalyzed synthesis of 3trifluoromethylated 1,3-dienes from acrylate derivatives and BTP. Tetrahedron 2018, 74, 60336040. (d) Zhao, Q.; Poisson, T.; Pannecoucke, X.; Bouillon, J.-P.; Besset, T. Pd-Catalyzed Diastereoselective Trifluoromethylthiolation of Functionalized Acrylamides. Org. Lett. 2017, 19, 51065109. (e) Zhao, Q.; Tognetti, V.; Joubert, L.; Besset, T.; Pannecoucke, X.; Bouillon, J.-P.; Poisson, T. PalladiumCatalyzed Synthesis of 3-Trifluoromethyl-Substituted 1,3-Butadienes by Means of Directed C-H Bond Functionalization. Org. Lett. 2017, 19, 2106-2109. (f) Zhao, Q.; Besset, T.; Poisson, T.; Bouillon, J.-P.; Pannecoucke, X. Palladium-Catalysed Synthesis of ?(Trifluoromethyl)Styrenes by Means of Directed C-H Bond Functionalization. Eur. J. Org. Chem. 2016, 7682. (g) Xiong, H.-Y.; Cahard, D.; Pannecoucke, X.; Besset, T. Pd-Catalyzed Directed Chlorination of Unactivated $\mathrm{C}\left(\mathrm{Sp}^{3}\right)-\mathrm{H}$ Bonds at Room Temperature. Eur. J. Org. Chem. 2016, 3625-3630. (h) Xiong, H.-Y.; 
Besset, T.; Cahard, D.; Pannecoucke, X. Palladium(II)Catalyzed Directed Trifluoromethylthiolation of Unactivated $\mathrm{C}\left(\mathrm{Sp}^{3}\right)-\mathrm{H}$ Bonds. J. Org. Chem. 2015, 80, 4204-4212. (i) Besset, T.; Cahard, D.; Pannecoucke, X. Regio- and Diastereoselective Cu-Mediated Trifluoromethylation of Functionalized Alkenes. J. Org. Chem. 2014, 79, 413-418.

(18) See the Supporting Information for details.

(19) When phthalimide bromide was used instead of NCS, the product resulting from the selective bromination of $1 \mathrm{a}$ at the C5 position of the 8aminoquinoline moiety was isolated in $66 \%$ yield.

(20) CCDC 2016282 contains the supplementary crystallographic data for this paper. These data can be obtained free of charge from The Cambridge Crystallographic Data Centre.

(21) Note that the ratio was determined on the crude mixture. The stereochemistry was ascertained by NMR experiments, see the supporting information for more details.

(22) Haines, B. E.; Xu, H.; Verma, P.; Wang, X.-C.; Yu, J.-Q.; Musaev, D. G. Mechanistic Details of $\mathrm{Pd}(\mathrm{II})$ Catalyzed $\mathrm{C}-\mathrm{H}$ lodination with Molecular $\mathrm{I}_{2}$ : Oxidative Addition vs Electrophilic Cleavage J. Am. Chem. Soc. 2015, 137, 9022-9031. 


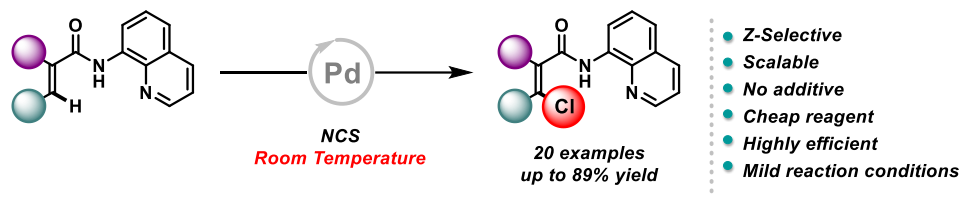

